Resumen por el autor, C. B. Moore, Leland Stanford Junior University.

Infecciones de la uretra femenina.

A causa de su estructura, posición y mecanismo de desplazamiento, la uretra femenina es muy propensa a la invasión bacterial. En ella se han encontrado una gran variedad de organismos. El gonococcus es el más importante, por su tendencia hacia la cronicidad y sus efectos nocivos. En las glándulas para-uretrales de Skene pueden presentarse infecciones supurativas crónicas, y también en las estructuras vestigiales de la glándula prostática, las cuales emiten pequeñas cantidades de pus de modo indefinido en la uretra anterior, sin que exista ningun síntoma local, por cuya causa no se descubren frecuentemente. La destrucción completa de estas glándulas, tal como puede conseguirse mediante el electro-cauterio, parece ser el único tratamiento que puede terminar de modo permanente las afecciones de dichas partes.

Translation by José $F$. Nonidez

Cornell Medical College, New York 


\title{
INFECTIONS IN THE FEMALE URETHRA
}

\author{
C. B. MOORE
}

Division of Obstetrics and Gynecology, Stanford School of Medicine, San Francisco

TEN FIGURES

In order to understand better the infections which occur in the female urethra and especially their tendency often to chronicity and the frequency with which they escape detection, a clinical and laboratory study of female urethras has been made during the last three years, together with a review of some of the literature which might be of assistance. The work in the laboratory comprises some bacteriological investigations and histological examinations of urethras of the newborn, infants, and adults of different ages. For the clinical studies, which were done at the same time in the Women's Clinic of the Stanford University School of Medicine, a new instrument was devised which has proved very satisfactory for the purpose of examining and treating the anterior urethra. Photographs of the microscopic sections and the instrument are appended below.

Because of its structure and location, the female urethra is very prone to bacterial invasion and retention, and for this reason is of distinct clinical interest both to the obstetrician and to the gynecologist. Infections occur here to a great extent only during the child-bearing period and it is not an uncommon focus of infection during pregnancy.

The female urethra is a fibromuscular structure about $35 \mathrm{~mm}$. in length, lying dorsally to the symphysis pubis and ventrally to the distal end of the anterior vaginal wall with which it is intimately associated. It is composed mostly of involuntary muscle fibers interwoven loosely with white fibrous and elastic tissue carrying numerous nerves and blood-vessels in its meshes, the corpus spongiosum. External to this appears two definite 
muscular coats, the inner, or longitudinal, and the outer, or circular coat. The latter forms a large ring, the unstriped sphincter, in the region of the vesicular neck; its reinforcement with striped muscle makes the striped or voluntary sphincter. The mucosa lining the canal is stratified squamous epithelium to a varying extent in the anterior end, stratified columnar epithelium in the intermediate region, and a transitional variety in the posterior end near the bladder. At the meatus of some subjects, especially nulliparous ones, the mucosa is extended into two lateral folds, called by Kelly (1) the labia urethrae. They vary in size and shape and undoubtedly assist in protecting the urethra from bacterial invasion from without. The urethral meatus usually lies about $10 \mathrm{~mm}$. from the anterior vaginal wall. In some subjects it lies even closer than this, sometimes a few millimeters. In the mechanism described below the meatus may come even to lie in a plane with the anterior vaginal wall.

The most important feature of the mucosa and the one giving rise to most, if not all, of the pathology is the glands, the most important ones of which are those of Skene. There are also many mucous or sinus glands found throughout its course. The latter structures are lined with short columnar epithelium and are sometimes called Littre glands. Skene's glands, usually two in number, lie beneath the mucosa posteriorly and near the meatus. They are individual, anatomic structures different from the crypts or sinus glands. Doctor Skene (2), of Brooklyn, in 1880, was the first one to discover these structures and realize their importance and to investigate their anatomy and some of their pathology. Dr. J. Kocks (3), of Bonn, and Prof. Max Schüller (4), a couple of years later, also investigated and described these para-urethral glands. The former considered them vestigial structures of the wollfian tubules.

These glands have their genesis in the prostate which is present in both sexes (5). The first anlage of the prostate in the female appears in embryos of $50 \mathrm{~mm}$.; in the male of $55 \mathrm{~mm}$. At first the prostate consists of solid epithelial buds which extend into the surrounding mesenchyme from the epithelium of the urogenital sinus, an early anterior division of the cloaca. Part of 
the anterior division of the cloaca goes to make the bladder and the urethra. These buds are most numerous on the dorsal surface, less so on the sides, and rarely on the ventral surface, although they may at times appear around the whole periphery. Those on the dorsal surface develop and branch, while those on the ventral surface remain simple and mostly degenerate. In the male these buds become enveloped in a fibromuscular mass to make the prostate gland. Some of the ducts which were not included in the formation of the prostate gland form accessory glands. According to Keibel and Mall, in the female embryo few glands are formed, three being the maximum number. These may undergo development and form the above-mentioned Skene's glands or ducts. This condition may possibly explain the different degrees of urethral infections in the female, at least to some extent. Since the glands are under retrogressive influences, they may not appear in some cases; in others they may be simple and shallow, in which case the infection is near the surface and therefore more easily cured; in others they may attain greater development, in which case infections become deep-seated and with poor drainage. This latter type leads to the chronic case described below which has been so difficult to cure.

In the embryo there are still other glands which develop in this region. These are the small sinus glands. They appear around the entire periphery of the urogenital sinus in the embryo of $60 \mathrm{~mm}$. These glands have the character of those of Bartholin, but do not attain to the same development. The gland of Bartholin, also developed from the urogenital sinus, comes to lie outside of the urethra, for which reason it does not enter into the present topic. Thus it is revealed from embryonic studies that there is considerable glandular development in this region. According to the distribution of these glands, the urethra is sometimes divided into an anterior and a posterior urethra, the former being the glandular region and the latter the nonglandular region (6).

The structure of Skene's para-urethral glands is described as follows (7): Upon each side, near the floor of the urethra, are 
two tubules extending from the vicinity of the meatus for $7 \mathrm{~mm}$. to $15 \mathrm{~mm}$. beneath the mucosa. The mouths of these tubes open upon the surface usually on either side of the median line about $3 \mathrm{~mm}$. from the outer border of the meatus. The upper ends of the tubules terminate in a number of divisions which branch off into the muscular walls of the urethra. These racemose structures are lined by a compound epithelium composed of three layers. The deepest layer is composed of young roundish cells having large, granular nuclei which make up the major portion of the cells. Next above this is a layer of cells of a somewhat spindle shape with prominent nuclei. They are young cells at a more advanced stage than those of the first layer. The next, or outermost, layer is composed of fully developed columnar epithelium with distinct nuclei arranged at the base of the cells. At the mouth or duct of the gland the columnar cells give place to a squamous epithelium resembling that of the anterior urethra. The structure of the epithelium of these glands gives evidence of considerable functional activity, which function is the production of a rather viscid mucus. The purpose of this secretion is undoubtedly to lubricate and protect the anterior urethra. Because infections of these glands had been found only in adults between the ages of twenty and thirty-five years, it has been stated that they appear to reach their best development between these ages (1). In our clinic they have been found to occur in patients between the ages of twenty and forty-eight years inclusively. The fact that they do not apparently appear in ages under twenty remairs to be explained. Possibly it may be due to a difference in the epithelial lining in very young patients. I have repeatedly examined the anterior urethras of young girls with chronic vaginitis, but have never succeeded in finding a suppurating focus in the urethra.

A great variety of organisms have been recovered from the human urethra (8): gonococcus, streptococcus, staphylococcus, diplococcus, colon bacillus, diptheria group of bacilli, pneumococcus, smegma bacilli, typhoid and typhus, pseudogonococci (an organism morphologically like the gonococcus, but Grampositive in reaction), and tuberculosis, and spirochaetae. The 
Micrococcus catarrhalis (a Gram-negative diplococcus resembling the gonococcus) has also been found in the urethra (9); also in the vagina (10), from which locality it may easily gain entrance to the urethra. A Gram-negative diplococcus having the form of the gonococcus, but with variations in size, has been demonstrated in preparations from fresh cultures (11): In smears taken from apparently normal urethrae, near the external meatus, we have always found some bacteria. Typhoid, typhus, and tuberculosis gain entry by invasion from within during the general infection of these diseases. A primary tuberculosis urethritis has yet to be definitely demonstrated. The inclusion bodies of Lindner (8), believed by many authorities to be the bacterium causing trachoma, have been recovered from the female urethra, the newborn of which patient had a conjunctivitis at the time. This same organism can be isolated from the infant's conjunctiva if smears are taken during the early onset of the inflammation. Virus from the mother's urethra, or from the infant's conjunctiva, or from a case of true trachoma will, when applied to the eyes of a monkey or human adult, produce trachoma. It is only when the germ gains entrance to the eye of the adult that true trachoma arises. So often has this been noted and by so many different observers that trachoma has been considered a venereal disease.

Infections in the urethra may be pathogenic or non-pathogenic, and also pyogenic or non-pyogenic. Because of its great prevalence and the extent of its ravages, the gonococcus is the infection of greatest importance. From the suppurating discharge expressed from the urethra Gram-negative intracellular diplococci can occasionally be demonstrated. But there are a great number of cases in which a great number of bacteria can be recovered without showing any presence of this bacterium, at least in smears made directly from the discharge. Knowing that the character of the gonococcus changes more or less during long habitation in the tissues, and also that a great variety of flora follow in its wake, chronic suppurating cases may be considered probably of Neisser origin unless otherwise demonstrated. Such a type of case may be shown in the following laboratory reports taken from the record of the Stanford Women's Clinic: 
No. 66510. July 22, 1918. Purulent-looking discharge expressed from urethral gland. Laboratory report of smear: Many pus cells and a few Gram-negative intracellular diplococci.

August 29, 1918. Purulent-looking discharge expressed from urethral gland. Laboratory report of smear: Many pus cells and epithelial cells and a few Gram-negative intracellular diplococci.

January 29, 1919. Purulent-looking discharge expressed from urethral gland. Laboratory report of smear: Many pus cells and Gramnegative and Gram-positive bacilli; no Gram-negative intracellular diplococci.

March 3, 1919. Purulent-looking discharge expressed from urethral gland. Laboratory report of smear: Many Gram-negative bacilli; no Gram-negative intracellular diplococci.

In subsequent smears no Gram-negative intracellular diplococci were found, although a purulent-looking discharge could be expressed every time the patient was examined. Such a case clearly indicates a great difficulty encountered in any bacteriological search for this bacterium.

In some cases Gram-negative, intracellular diplococci may be present in the urethra without giving rise to any urethral signs or symptoms, as illustrated in the following record:

No. 74194. Cervicitis. Thick, mucopurulent discharge from the cervix. No discharge from the urethra; anterior urethra clear. Laboratory report: Cervical smear: Many endothelial cells and a few Grampositive bacilli. No Gram-negative intracellular diplococci seen. Smear from anterior urethra: Gram-negative intracellular diplococci: Many Gram-positive diplococci and bacilli.

What organism this is we cannot say at present. It appears that this bacterium is either in the incubation stage or else has remained here without producing any pathology.

B. coli infections producing suppurating para-urethral glands have been described by Fellner (12).

The changes in the urethra following pathogenic infections may be divided into two classes: those due to simple inflammation and those due to suppuration. In the former the lesion is like that of inflammation of a mucous membrane. These usually disappear in time or else yield to urinary antiseptics, except possibly some few chronic cases affecting the intermediate region. The squamous epithelium of the anterior urethra does not offer 
proper soil for the invasion of bacteria. Luys (6) has described the changes due to gonorrhoeal infections. Tuberculosis (13) and syphilis $(14,15)$ have their specific lesions, which are described under these diseases.

The pyogenic infections are very important because of their frequency and chronicity. However, it should be noted that there can be expressed from some female urethras a material which is not one of suppuration. Sometimes a thick, creamy discharge, sometimes cheesy in consistency, can be expressed in which smegma bacilli have been found. At times one may be able to express a considerable amount of this material from the urethra. Occasionally a thin or thick white discharge is seen in the anterior urethra or can even be expressed directly from a gland, a material looking like that seen in the vagina at the time. This discharge has apparently passed from the latter place and lodged in the anterior urethra or gained access to a gland. The stained smears from each locality are alike. This condition is demonstrated in the following record:

No. 78639. Moderately thick whitish discharge in vagina. Moderately thick whitish discharge expressed from gland in floor of anterior urethra, right side. Smears made from each locality. Laboratory report: Urethral smear: Examination shows many epithelial cells which are squamous in type and have been denuded in masses. No pus cells nor lymphocytes seen. Many bacteria of various types, including large and small bacilli and small diplococci. Vaginal smear: Shows moderate number of squamous epithelial cells, a few lymphocytes, but no pus cells; numerous bacteria of various types, including large and small bacilli and small cocci occurring singly, in pairs, and in masses.

On two subsequent examinations at intervals of seven days, the same discharge was expressed from the same region of the urethra. Because the excretion resembles that seen in the vagina, macroscopically and microscopically, it is probable that the process was initiated by extension from the latter place or vice versa, and apparently does not extend beyond that of desquamation. In the chronic cases with suppurating infections we have a condition in which the original surface infection hàs disappeared; the bacteria have penetrated into the glands which offer the best soil for bacterial growth. In these minute 
epithelial pockets chronic inflammation with suppuration may go on indefinitely and without a local symptom. At every examination of these patients one or more drops of pus can be expressed into the urethral meatus from these suppurating glands.

When the duct of a suppurating gland becomes occluded there will be formed a para-urethral abscess which may vary from the size of a marble to that of a large walnut. In the larger abscesses the mucous membrane and vascular capillaries have been destroyed in places and the process has extended into the adjacent tissue. In this way blood sometimes becomes mixed with the pus.

An important point which may be considered here is the way in which the discharge from the urethra may be carried up into the parturient tract of an obstetrical patient. In his description of the function of Skene's glands, namely, lubrication during coitus, Kelly has described a mechanism of displacement and eversion of the urethra which may be seen to take place when a finger is introduced into the vagina. At the first contact the labia urethrae are separated. This opens the urethral orifice. The tendency of the act of penetration is to displace the distal end of the urethra dorsally: As the vaginal wall becomes impinged upon, the displacement will become even more marked and the urethral orifice directed into the vagina. Thus during the examination of an obstetrical patient the urethral meatus tends to become directed toward the examining finger. Pressure on the anterior vaginal wall expresses any infected contents of the urethral glands, which are then carried up into the vagina by the penetrating finger. For this reason, unless one be exceedingly careful, a digital examination of an obstetrical patient had better be done per rectum. Also by this same mechanism infections may be carried to or into the urethral meatus. This is probably the way in which $\mathrm{B}$. coli enter the urinary tract in the newly married, giving rise to what is called by Sippel (16) 'Kohabitation Cystitis und Pyelitis.' No matter how slight the abrasion of the urethral meatus which is directed into the vagina during the act of penetration, colon bacilli, which are 
commonly present in this region, become rubbed in and thereby enter the urethral lymphatics and ascend. Some of these cases of B. coli infection disappear spontaneously; others lose their acute character, if they had any, and continue without symptoms, a chronic condition with acute exacerbations of pyelocystitis, commonly called by the laity 'bilious attacks.' This is also a probable way in which pyelitis of pregnancy develops.

Whenever a suppurating discharge can be expressed from the urethral glands I do not think it worth while to treat the infection with antiseptic instillation into the urethra or even directly into the ducts of the gland. Many of the cases so treated continue to discharge pus with little or no interruption. If the patient is kept under observation long enough, it will sometimes be found that what was thought to be cured was only pus-free for a time and has returned to its former suppurating condition.

Anterior urethral glands can easily be destroyed with the electric cautery and the suppurating condition terminated if the cauterization is sufficiently done. Whenever it is certain that the discharge expressed from the urethra is pus the anterior urethra should be cocainized with a 10 per cent solution of cocaine and the skenoscope (17) introduced. Sometimes one may be able to see the entrance to the ducts. With a finger in the vagina and pressure applied along the urethra, pus may be seen to appear at one or two spots on the mucosa. In one instance, I saw as many as three drops appear at the same time in different places, and in a lateral position, not in the usual position on the floor of the urethra. At times one will be surprised to find that he is unable to express any discharge from a urethral gland, although some emerged from the meatus on examination before the instrument was introduced. This may be due to the fact that all of it had been expressed either from a gland or from the anterior urethra where it was lying. To tell whether or not it has come from a gland it is necessary to make the examination with the anterior urethra exposed so that the definite locality of any discharge may be seen. In case of failure to express any excretion for the reason just mentioned, the patient may be requested to return for another examination in a few days. The 
instrument is then introduced for the preliminary search. The gland will be found to have filled again, especially so if pus had been found, and the discharge will be seen to emerge from its orifice on pressure. With a small wire a search is made in each drop of pus for the entrance to the duct into which the wire is passed as far as possible. This will act as a guide to direct the passage of a small wire electrocautery. Cauterize until as much tissue is destroyed as one thinks advisable. Failing to find the entrance to the duct one may cauterize the region with no guide other than the eye. If on a subsequent visit the treatment has been found to be unsuccessful or pus has appeared from another locality, the treatment should be repeated. I have never seen any ill effects follow this treatment and no recurrence after the second cauterization, which is usually more thoroughly done than the first one. Healing is very prompt. Also, I have never seen any suppurating gland further than a few millimeters from the meatus; never beyond easy reach of the cautery, and never more than one or two in number, on one occasion three. This fact, together with Keibel's and Mall's embryonic studies, leads me to believe that all of these cases are those of skenitis.

Para-urethral abscesses which cannot be emptied through the duct should be treated surgically by incision and drainage.

I wish to thank Dr. Frank Ellsworth Blaisdell for his help and assistance in examining the histological sections and for his contributions of microphotographs which accompany this paper. Thanks is also due others of my confreres whose interest has been an encouragement. 


\section{LITERATURE CITED}

1 KeLLY, Howard A. 1903 Labia urethrae and Skene's glands. American Medicine, vol. 6, pp. 429 and 465.

2 Skene, A. J. C. 1880 The anatomy and pathology of two important glands of the female urethra. American Journal Obs., vol. 8, p. 265.

3 Kochs, J. 1886 Uber die Gartnerschen Gange beim Weibe. Arch. f. Gynäkologie. Red. von Crede; Bd. 20. Berlin.

4 SchÜller, MAX 1883 Ein Beitrag zur Anatomie der weiblichen Harnröhre. a) Virchow's Archiv für pathologische Anatomie und Physiologie und für klinische Medicin, Bd. 94, S. 405. b) Festschrift f. Bernard Schultz, Berlin, Bd. 4, S. 16.

5 Keibel, Franz, and Mall, Franklin P. 1912 Human embryology, vol. 2, chap. 19, p. 965. J. B. Lippincott Company, Philadelphia and London.

6 Loys, Gebrge A textbook of gonorrhoea, pp. 66-75. Bailliere, Tindall \& Cox, Covent Garden, London.

7 Van Cot', Joshua M. 1888 The histology and pathology of Skene's glands. Brooklyn Med. Jour., vol. 1, p. 132.

8 Konigstein, H. Urethritis non-gonorrhoeal bei Mann und Frau. Handbuch der Geschlechtskrankheiten, Bd. 2, S. 518-575.

9 Ayers, W. 1912 The Micrococcus catarrhalis as a cause of inflammation in the genito-urinary tract. Amer. Jour. Surg. N. Y., March, p. 101.

10 Gurd, Fraser B. 1908 A contribution to the bacteriology of the female genital tract with special reference to the gonococcus. Jour. Med. Research, vol. 18, N. S. 13, p. 291.

11 Steinschneider 1893 Utber die Cultur der Gonokokken. Berliner klinische Wochenschrift, July 24, S. 969.

12 Fellner, Otfried O. Einige Fälle von paraurethraler Eiterung bei Weib. Monatschr. f. Geburtsh. u. Gyn., Bd. 25, S. 319.

13 Hartmann, H. 1905 Tuberculose hypertrophique et stenosante de l'urethre chez la femme. Bull. et M. Sec. de chir. de Par., N. S., T. 32, pp. 956-958.

14 Douelle, M. 1901 Chancre syphilitique de l'urethre chez une femme. T. D. mal. cutan. et syph., Par., T. 13, pp. 467-471.

15 Lewembach, G. 1903 Die gummose Erkrankung der weiblichen Urethrae. Ztschr. f. Heilk., Wien u. Leipzig, 6 pl.; S. 51-91.

16 Sippel, A. 1912 Aufsteigende Infektion der Harnwege bei frisch verheirateten Frauen. Kohabitation Cystitis und Pyelitis. Dut. med.' Wochensch., Jun. 13, Bd. 28; S. 1138.

17 Moore, C. B. 1918 Chronic gonorrhoeal skenitis. Treatment with the electrocautery. Jour. Amer. Med. Assoc., Dec. 21, vol. 71, p. 2056. 


\section{PLATE 1}

\section{EXPLANATION OF FIGURES}

1 Cross-section of a female urethra near meatus of a newborn baby. $G$, glands; $U$, urethral canal. Abundant squamous epithelium.

2 Higher magnification of a region on figure 1. All sections of this specimen show this type of epithelium.

3 Cross-section of the whole specimen of a female urethra near meatus of a nine months' baby. As disclosed in embryonic studies, the glanudular budding is greater on the dorsal side. 

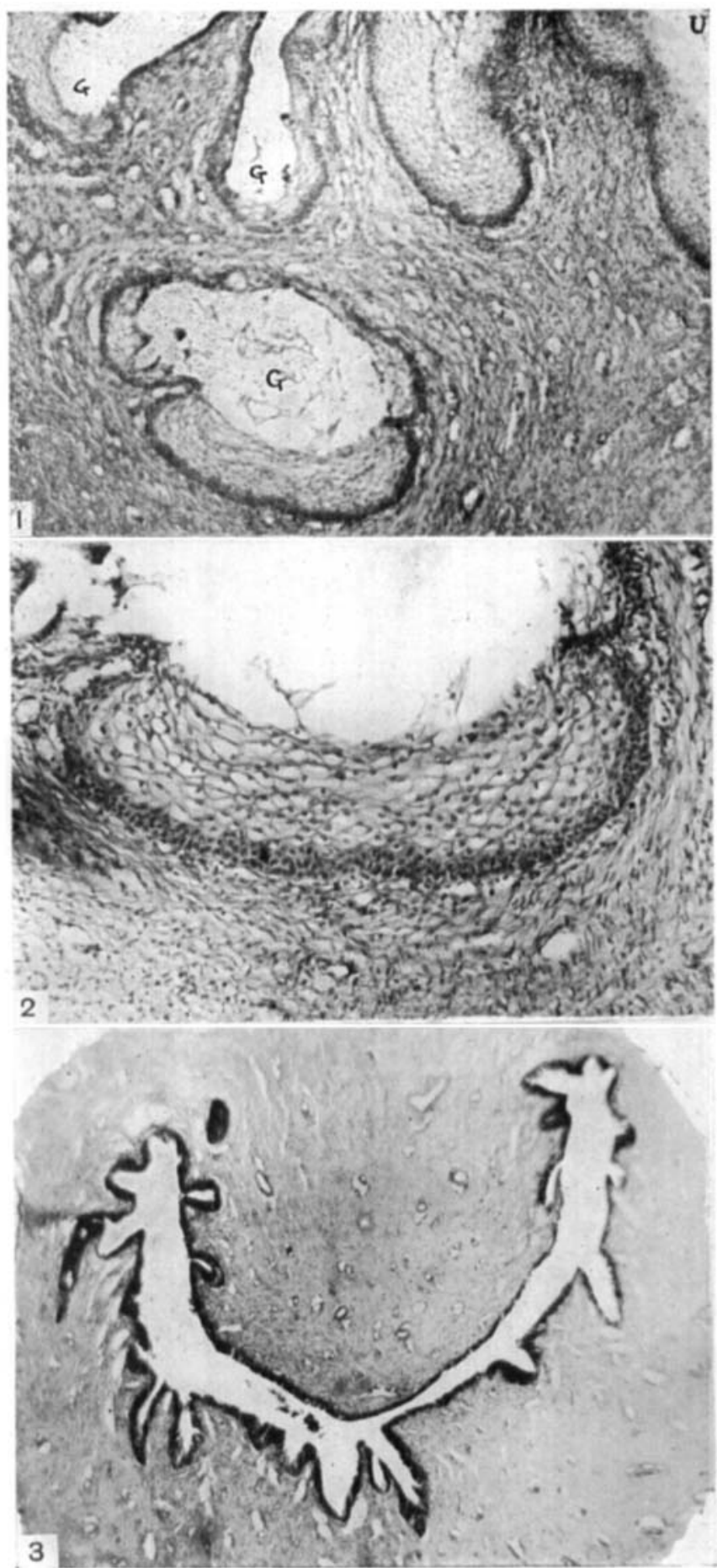
PLATE 2

EXPLANATION OF FIGURES

4 Cross-section of a female urethra near meatus of a nine months' baby; made from a region of figure 3 . $G$, gland; $U$, urethral canal.

5 Cross-section of a female urethra near meatus of a twenty-three-year-old subject. Epithelium is squamous. This is undoubtedly a Skene's gland. $U$, urethral canal; $D$, duct; $G$, gland.

6 Higher magnification of a region on figure 5 , but made $\frac{5}{1} \sigma \mathrm{mm}$. posterior to the section made of the latter. This section shows columnar epithelium of the urethral canal, $U$, and the gland, $G$.

7 Cross-section of a femalc urethra near meatus of a forty-three-year-old subject. $G$, gland; $E$, epithelium; $U$, urethral canal. 


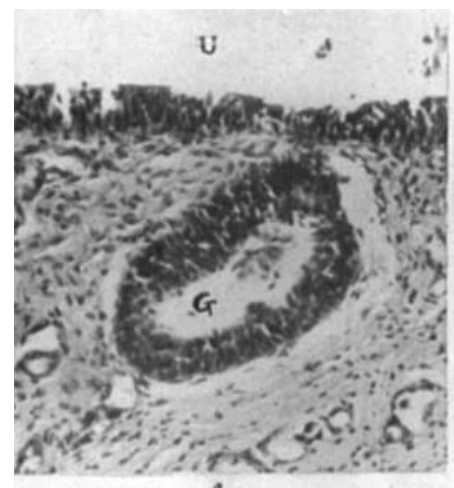

4

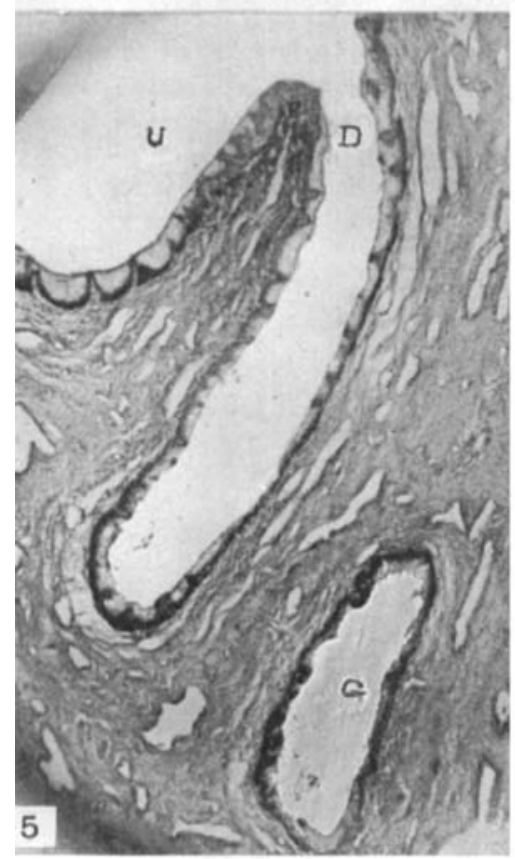

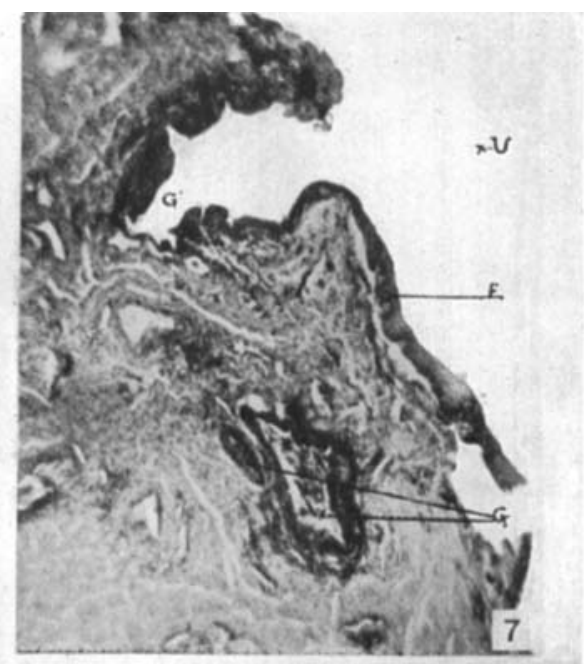

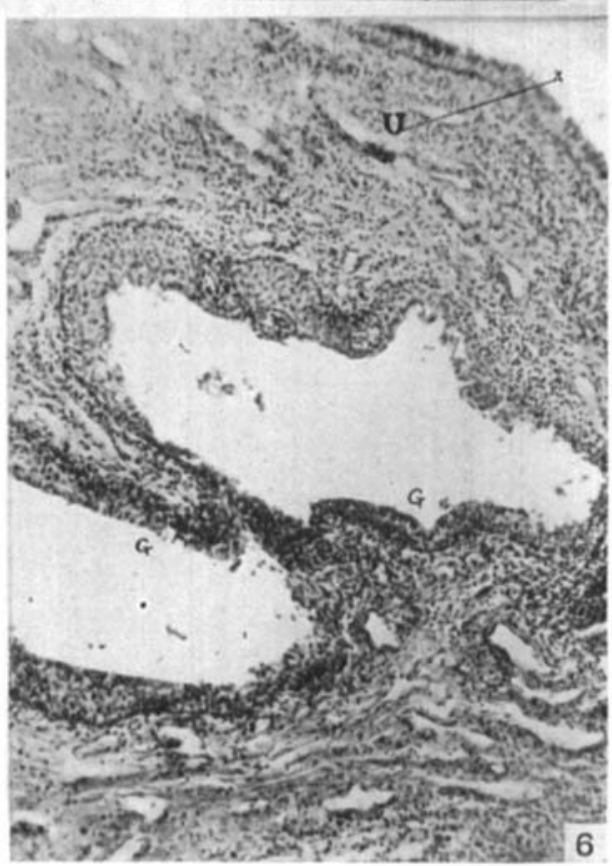




\section{PLATE 3}

\section{EXPLANATION OF FIGURES}

8 Drawing of a sagittal section through the center of a female pelvis representing the urethral displacement on vaginal penetration.

9 Instrument in position for examination and treatment. Exposure of drops of pus $(A)$ in different localities of the urethra in different subjects.

10 Skenoscope. 
C. B. MOORE

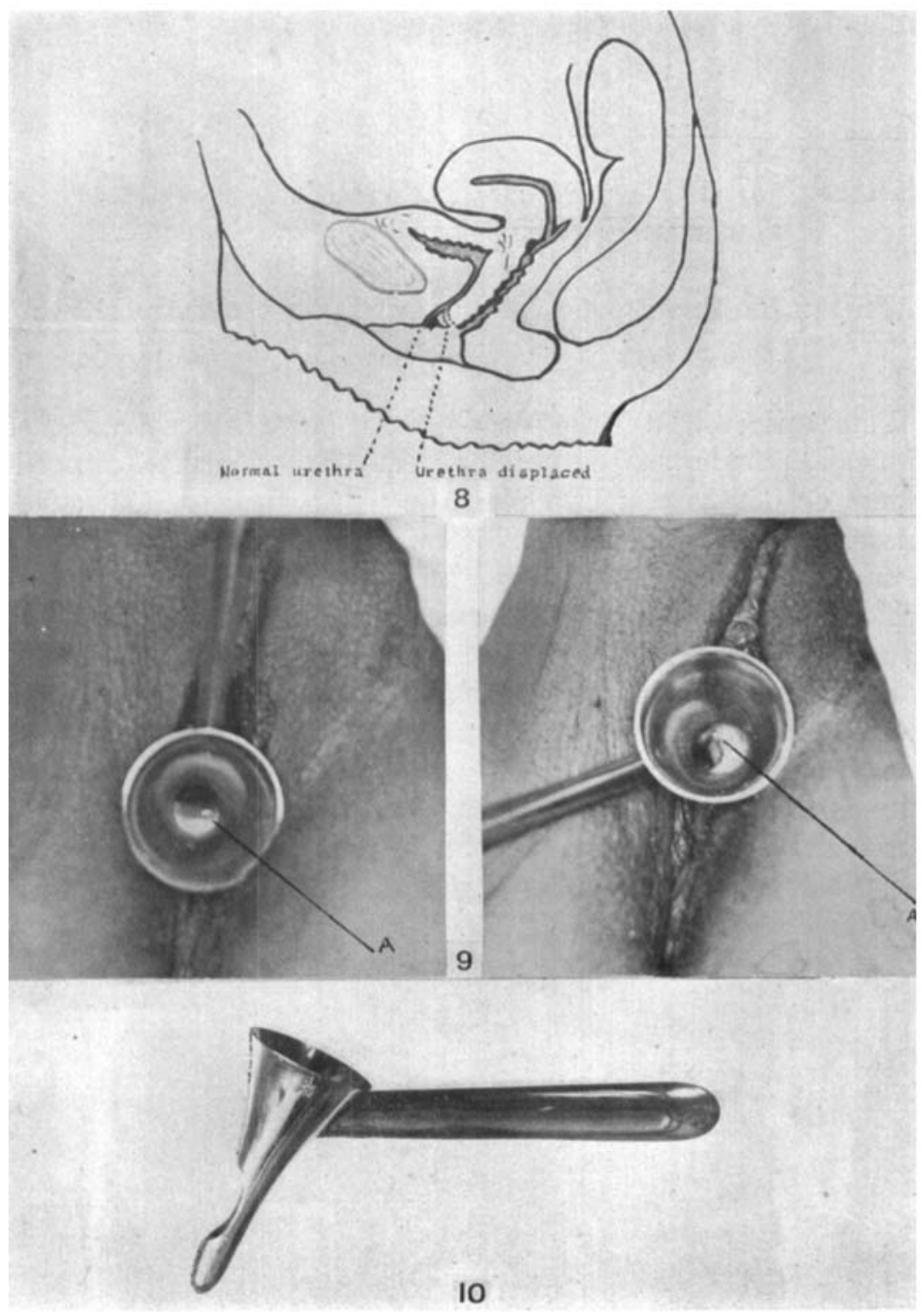

